\title{
ARTUR JAZDON
}

Maja Wojciechowska, Studium zarzadzania niematerialnymi zasobami organizacyjnymi bibliotek, Gdańsk: Wydawnictwo Uniwersytetu Gdańskiego 2014, s. 338

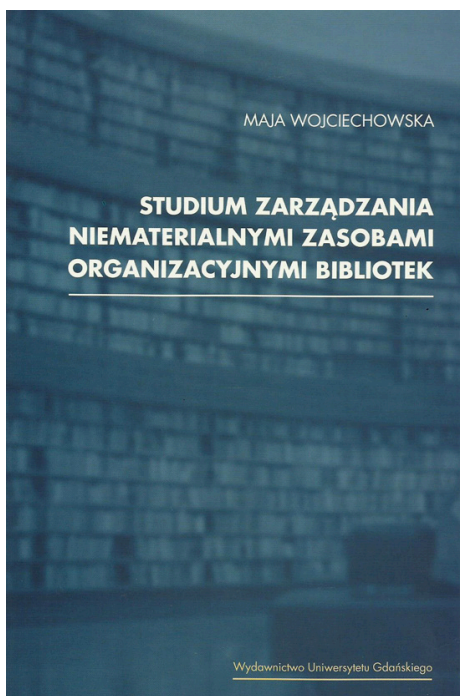

Recenzowana monografia habilitacyjna jest obszernym - składającym się z trzech rozbudowanych wewnętrznie rozdziałów uzupełnionych tabelami i rysunkami opracowaniem, opartym na bogatej literaturze zagranicznej i krajowej, bibliologicznej i szerszej z zakresu ekonomii. Poświęcone zostało zgodnie z intencjami autorki aktualnym, a mało jeszcze zbadanym problemom aktywów niematerialnych, ich funkcjonowania, wartości oraz roli, jaką odgrywają w kształtowaniu usług informacyjnych, a także kompetencjom niezbędnym dla zarządzania nimi, w celu podnoszenia jakości świadczonych usług i skuteczności działania biblioteki. Autorka - stojąc na stanowisku, że prawdziwa jest teza teoretyków z tzw. szkoły zasobów, mówiących, że powodzenie organizacji zależy od skutecznego zarządzania niematerialnymi zasobami wewnętrznymi oraz od rozwoju i wykorzystania wyróżniających ją kompetencji kluczowych - pragnie swym opracowaniem przybliżyć podstawy tych założeń oraz w wyniku przeprowadzonych badań wykazać, które z zasobów niematerialnych są najwyżej cenione przez kadrę kierowniczą polskich bibliotek, które uznaje ona za decydujące o sukcesie tych instytucji w otoczeniu. Walorem pracy jest więc zarówno podjęta próba teoretycznego przeniesienia na grunt polskich bibliotek modelu ich badania i rozwiązywania ich problemów dzięki zastosowaniu metod charakterystycznych dla instytucji komercyjnych, jak też 
przedstawienie analizy wyników przeprowadzonych badań, które winny stać się punktem wyjścia do podejmowania tych zagadnień w praktycznych działaniach zarządów bibliotek.

Podjęcie tego tematu ze względu na jego pionierski, w tak kompleksowym spojrzeniu, charakter należy uznać za bardzo ważne.

W pierwszym rozdziale autorka przedstawiła tematykę zasobów niematerialnych, kształtowania się definicji tego pojęcia, zróżnicowanego jego ujmowania, a tym samym szczegółowej problematyki w ramach różnych propozycji teoretycznych. Wnikliwa analiza pozwala autorce uznać za prawomocne stwierdzenie, że brak jest jednoznacznej definicji czy wśród propozycji takiej, którą można by uznać za zasadniczą. Wniosek ten jest właściwy i w pełni udokumentowany. Na podstawie tych rozważań autorka przedstawiła swą propozycję podziału zasobów biblioteki na materialne i niematerialne (s. 31). Niematerialne omawia w dalszej części pracy. Przedstawiony pomysł typowania niematerialnych zasobów jest pochodną różnych omówionych poprzednio propozycji i nie wzbudza zasadniczych zastrzeżeń czy uwag. Należy się zgodzić z uwagą autorki, że każda konkretna biblioteka, w zależności od swego charakteru, przypisywanego jej katalogu zadań, kładzie nacisk na różne wartości i posiada indywidualny i niepowtarzalny ich zasób. Wyprzedzając niejako dalszą zawartość analizowanej pracy, można więc zadać pytanie, czy zasadne było dla próby budowania modelu prowadzenie badań $\mathrm{w}$ tak zróżnicowanych grupach jak duże biblioteki naukowe czy publiczne i np. biblioteki szkolne. W przypadku tych ostatnich, jak i małych publicznych, filialnych, zakładowych itp. trudno mówić np. o marce, swoistej kulturze organizacyjnej, działaniu w sieciach i konsorcjach. Jest to ważne w kontekście innej, prawidłowej konkluzji autorki, że zasoby niematerialne wzajemnie na siebie oddziałują, tworząc skumulowaną wartość, i że nie można traktować ich jako odrębnych, niezależnych od siebie czynników (s. 39). Jednakże zupełnie odmienny będzie on w każdym z przywołanych, krańcowych typów bibliotek, co utrudnia według mnie czy wręcz uniemożliwia łączne badanie i rozpatrywanie tak odmiennych pod każdym względem instytucji.

Rozdział drugi jest najważniejszy w monografii, gdyż autorka podjęła w nim próbę analizy zasobów niematerialnych bibliotek uznanych uprzednio za zasadnicze. W nim także zawarła część z wyników badań przeprowadzonych wśród kadry kierowniczej, ilustrując w ten sposób omawiane teoretycznie zagadnienia. Pierwszym elementem budującym zasoby niematerialne jest według autorki kapitał ludzki. Specyficzny, ponieważ niestanowiący własności organizacji, pozostający tylko w jej dyspozycji, ale decydujący o budowaniu innych zasobów niematerialnych 
biblioteki (reputacja, marka czy kultura organizacyjna). Tym bardziej zastanawiające są - co nie oznacza, że kontestowane przeze mnie - rezultaty badań, które świadczą o tym, że praktycznie stosowane sposoby zarządzania personelem $\mathrm{w}$ polskich bibliotekach nie przystają do przypisywanej temu zasobowi rangi. Czy wynika to przede wszystkim z ograniczeń finansowych, jak stwierdza autorka (s. 88)? Niestety, śmiem twierdzić, że nie tylko i problem ma głębsze podłoże, tkwiące $w$ psychice, ograniczeniach dużej części zarządzających, wykorzystujących tylko element „niemocy finansowej" jako wygodny parawan dla swych decyzji.

Związany z tym jest drugi z analizowanych zasobów, za jaki Wojciechowska - i słusznie - uznaje przywództwo, jako łącznik pomiędzy kapitałem ludzkim a strukturalnym biblioteki. Trzeba się zgodzić z autorka, że dobre przywództwo to nie tylko kierowanie personelem i budowanie kultury organizacyjnej, założeń strategii, metod zarządzania, ale i umiejętność mobilizacji, odpowiedniej integracji personelu wokół i dla jak najlepszego realizowania misji biblioteki. Na s. 109 znajdujemy dość smutną konkluzję, którą autorka powiąże ze swymi uwagami podsumowującymi podrozdział poprzedni, że problemem przywództwa współczesnych bibliotek jest niedobór kadry menedżerskiej posiadającej kompetencje zarówno fachowe, jak i przywódcze.

Ze wszystkimi przytoczonymi przez autorkę rozważaniami dotyczącymi kultury organizacyjnej należy się zgodzić. Podsumowanie podrozdziału, w którym Wojciechowska uwypukla zalety kultury właściwej dla danej organizacji, jej wpływ na inne składniki zasobów niematerialnych itp., stanowi zebranie omówionych uprzednio poglądów wielu twórców. Charakterystyczne dla autorki jest przedostatnie zdanie, w którym przeciwstawia poglądy dwóch grup badaczy (s. 143). Ważne dla czytelnika byłoby przedstawienie jej stanowiska w tej kwestii, abyśmy mogli poznać jej opinię na dany temat. Takie sytuacje braku wyraźnego opowiedzenia się Wojciechowskiej i poprzestanie na zreferowaniu poglądów innych autorów niestety się powtarzają.

Podobne uwagi można wyrazić na temat dwóch kolejnych podrozdziałów dotyczących reputacji i marki. Ponownie bowiem przytoczone na ich temat rozważania i konkluzje końcowe nie wzbudzają zastrzeżeń. $\mathrm{W}$ pierwszym $\mathrm{z}$ nich interesująca jest szczegółowa tabela zbierająca wyniki przeprowadzonych przez autorkę badań opinii otoczenia na temat działalności usługowej biblioteki. Obszerność tabeli (s. 171-181) już sama w sobie mówi o bogactwie materiału do analizy, który nie został w opracowaniu przez autorkę dostatecznie wykorzystany. Wnioski z tabeli zamknęła bowiem w 16 wierszach, nie wiążąc wystarczająco zależności wynikających z badań. 
Konkluzja podrozdziału dotyczącego elastyczności i innowacyjności jest jak najwłaściwsza, ponieważ faktycznie należy uznać, że są one zależne bardzo od innych wartości niematerialnych. Autorka zauważa, że biblioteki nie są ze swej natury instytucjami generującymi liczne innowacje. Szczególnie gdy spojrzymy na to z punktu widzenia innowacji wykorzystywanych następnie $w$ innych sektorach, sferach życia społecznego. Jednakże wydaje się, że w kontekście przytoczonych poprzednio badań (tabela na s. 171-181) winny one nie tylko „utrzymywać pewien poziom zmian gwarantujących atrakcyjność i aktualność usług", jak stwierdza autorka (s. 217). We właściwym dla siebie zakresie, adekwatnie do swych możliwości powinny je stale proponować, wprowadzać, szeroko o nich informować, badać potrzeby ich wdrażania, następnie ich odbiór, ponieważ należy uznać, że we współczesnym społeczeństwie - czy nam się podoba, czy nie, czy uznamy to za słuszne, czy nie - taka elastyczność i innowacyjna atrakcyjność są dla odbiorców niezwykle ważnymi elementami. I nie ma tu co czekać (s. 217), czy narzekać na niezadawalające stymulowanie innowacyjności przez odpowiednie kształtowanie polityki państwa czy choć według mnie w mniejszym zakresie - polityki regionalnej, gdyż $\mathrm{w}$ największym stopniu wynika ona z rozpoznania potrzeb własnej grupy użytkowników i elastycznym proponowaniu narzędzi, usług, zasobów zaspokajających te potrzeby. Dzięki swej innowacyjności biblioteka staje się miejscem atrakcyjnym dla użytkowników.

Ostatnie trzy podrozdziały są związane z aspektami, które w skromniejszym zakresie można zaliczyć w przypadku każdej biblioteki do jej zasobów niematerialnych, czy w mniejszym pewnie stopniu decydują o tym jej zasobie. Pierwszy z nich dotyczy w zasadzie "zdolności do współpracy" i takie sformułowanie byłoby mniej dyskusyjne niż zaproponowane "sieci i konsorcja”. Zabrakło mi jasnego stwierdzenia, że uczestnictwo $\mathrm{w}$ nich przybliża każdą z bibliotek do modelu e-zarządzania, z tymi najbardziej pożądanymi tegoż elementami: ograniczenia własnych nakładów finansowych i pracy dla osiągnięcia końcowego efektu (realizacja oczekiwań użytkowników także przez przejmowanie innowacyjnych rozwiązań, usług, zasobów tworzonych przez innych) z możliwością wykorzystania własnego potencjału dla budowania nowatorskich rozwiązań (przejmowanych w ramach e-zarządzania przez innych!), ale tym samym budowania specjalizacji, wyróżniającej marki, przewagi konkurencyjnej. A więc wykorzystania działania w sieci dla zwiększenia własnych niematerialnych zasobów organizacyjnych.

Włączenie do rozważań jako wydzielonego elementu obsługi nowych technologii i procesów wydaje się dyskusyjne. Dyskusyjne nie jest to, że są one ważnymi elementami w działaniu biblioteki, ale to, że wiążą się 
bardzo z poprzednio już omówionymi takimi zasobami jak kapitał ludzki czy innowacyjność. Trudno na przykład wyobrazić sobie pracowników niepotrafiących dziś wykorzystywać nowych technologii, a zasób kadrowy (ze swą wiedzą i umiejętnościami praktycznymi) autorka uznała za podstawowy. Na początku recenzji użyłem sformułowania, że konstrukcja rozdziału drugiego nie wzbudza zasadniczych uwag, ponieważ wydzielenie tego właśnie podrozdziału uznaję za dyskusyjne.

Podobnie, choć z innych przyczyn, można dyskutować nad wydzieleniem podrozdziału ostatniego - Własność intelektualna, gdyż rzadko może ona stanowić w rzeczywistości wartość biblioteki ze względu na fakt, że bardzo sporadycznie będzie ona wytwarzana w bibliotece. A tylko w tym wypadku stanowi wartość, zasób danej biblioteki, w pozostałych biblioteka tylko ją wykorzystuje w swej działalności.

Cały rozdział drugi zdaje się $\mathrm{w}$ pewnych fragmentach przeładowany streszczaniem, przytaczaniem wielu poglądów teoretycznych innych badaczy, nieodnoszących się do bibliotekarstwa. Dość często odnosiłem przy tym wrażenie, że wstawienie w daną opinię czy zdanie słowa „biblioteka" jest nienaturalne. Potwierdza to odczucie przyjrzenie się tytułowi artykułu czy książki, do których autorka odsyła czytelnika. Ale to może tylko kwestia stylu Wojciechowskiej. Minusem jest próba pogłębienia tematu przez przechodzenie do coraz to dalszych szczegółowych elementów, które z konieczności muszą być potraktowane ogólnie czy nie mają znaczenia dla analizy omawianego zagadnienia. Przykładem niech będzie choćby podrozdział na temat przywództwa, w którym autorka (s. 103-104) - jak sama pisze - „na marginesie” omawia model stworzony przez Johna Adaira, nie odnosząc go w żaden sposób do bibliotek, a ta organizacja nas interesuje. W podrozdziale dotyczącym strategii pierwszych kilkanaście stron poświęcono omówieniu spraw znanych, opisanych w literaturze, a niewnoszących nic bezpośrednio do rozważań, $\mathrm{np}$. definiowaniu pojęcia strategia z odwołaniem do... starożytnej Grecji, czy przypominaniu planu budowy strategii, poszczególnych jej etapów, kontekstów narzędziowych itp. Wszystko to, co pisze Wojciechowska, jest zgodne z prawda, ale należy założyć, że czytelnik tej monografii takie zagadnienia już zna i interesują go nie podręcznikowe założenia teoretyczne, ale wskazanie roli strategii jako zasobu niematerialnego, czynników pozytywnie czy negatywnie oddziałujących na jej budowanie w bibliotekach itp.

W ostatnim, trzecim rozdziale autorka analizuje zagadnienia zarządzania zasobami niematerialnymi $\mathrm{w}$ bibliotece. Wraca więc do swych zainteresowań badawczych z etapu przygotowywania rozprawy doktorskiej, co nie jest wskazywane tu jako słabość! Można założyć, że po kolejnych 
latach badań, dojrzewania i rozwoju Wojciechowska jest w stanie głębiej spojrzeć na te zagadnienia, a $\mathrm{w}$ dodatku podjać próbę odpowiedzi na pytanie, czy w ciągu lat dzielących badania zmieniła się - oceniona nie najwyżej w pierwszej publikacji - świadomość kadry zarządzającej na temat organizowania i przeprowadzania zmian w bibliotekach.

$\mathrm{W}$ pierwszych trzech podrozdziałach autorka szeroko omawia wiele różnych modeli zarządzania zasobami niematerialnymi oraz ich pomiarów. Dokonany i w tym rozdziale - jak w poprzednim - tak obszerny przegląd świadczy dobrze o znajomości literatury (nie tylko czysto bibliologicznej) z tego zakresu tematycznego i daje czytelnikowi możliwość samodzielnych analiz. Ponownie, szczególnie w drugim z podrozdziałów, brakuje mi głębszego odniesienia omówionych propozycji do potrzeb bibliotek czy zgłoszenia - mam świadomość: $w$ pełni pionierskiej, a więc nawet wstępnej - propozycji, jak realizować te pomiary w naszych instytucjach. Trzeba stwierdzić, że w ostatnim podrozdziale Wojciechowska wskazuje możliwość zastosowania w bibliotekach modelu zaproponowanego przez Agnieszkę Sopińską i Piotra Wachowiaka (s. 279-283) i być może $\mathrm{w}$ tym analizowanym podrozdziale należało to uwzględnić. Pracę zamyka przedstawienie wyników badań autorki przeprowadzonych $\mathrm{w}$ polskich bibliotekach. Wynika $\mathrm{z}$ nich niezbicie, że pomimo uznania wysokiej wartości zasobów niematerialnych działania związane z ich badaniem, pomiarem, a także świadomym zarządzaniem nimi pozostają na niskim poziomie. Przeprowadzenie przez Wojciechowską badań, na których wyniki powołuje się w pracy, mimo zgłoszonych uprzednio zastrzeżeń, należy uznać za niezwykle ważne. Konsekwencją wyrażonych spostrzeżeń i konkluzji winno się stać podjęcie różnorodnych działań dla poprawy sytuacji w tym zakresie. Należy bowiem zgodzić się z autorka, że choć biblioteki różnią się od instytucji o nastawieniu komercyjnym, to funkcjonują w takich a nie innych realiach społeczno-gospodarczych, są organizacjami społecznymi mocno powiązanymi z innymi elementami otoczenia dalszego i bliższego i powinny stosować - bo im podlegają obowiązujące powszechnie reguły. Autorka wykazała w swej pracy duże zaległości czy zapóźnienia pod tymi względami w naszych bibliotekach. Potrzebne jest przenoszenie na nasz grunt nie tylko rozwiązań teoretycznych - te autorka zaprezentowała w szerokim wyborze - ale też konkretnych działań szkoleniowych, warsztatowych uświadamiających wagę problemu i sposoby praktycznego ich rozwiązywania.

Ze względu na pionierski charakter, aktualność podjętej tematyki, duże walory poznawcze, połączenie studiów literaturoznawczych z badaniami własnymi, mimo drobnych wskazanych zastrzeżeń, a może podniesionych zagadnień dyskusyjnych, wysoko należy ocenić przedstawioną 
monografię i stwierdzić, że zakładana teza badawcza, iż zasadne i możliwe jest wykorzystanie teorii zasobowej na potrzeby polskich bibliotek, została wykazana. Książka winna stać się lekturą obowiązkową nie tylko studentów bibliotekoznawstwa, ale także praktyków już zarządzających czy przymierzających się do zarządzania bibliotekami. 